\author{
Review Article
}

\title{
A LIMELIGHT ON THE AFFIRMATIVE IMPACT OF KRIYAKALPAS APROPOS OF THE SENSE ORGANS AND ITS MANAGEMENT IN THE EPIDEMIOLOGICAL DISEASES-AN OVERVIEW
}

\section{Rengapadmini B ${ }^{*}$, Balasubramaniam S1, Anita Patel2}

*1PG Scholar, ${ }^{2}$ Associate Professor, Dept. of Shalya Tantra, Sri Jayendra Saraswathi Ayurveda College and Hospital, Chennai, Department of Ayurveda, Sri Chandrasekharendra Saraswathi Vishwa Mahavidyalaya, Kanchipuram.

Article info

Article History:

Received: 29-11-2021

Revised: 17-12-2021

Accepted: 28-12-2021

\section{KEYWORDS:}

Pandemic; Epidemic; Kriyakalpam; Janapadhodhwamsam; Uttamangam.

\begin{abstract}
Ever since the days of yore, the infectious pandemics of natural or man-made origin greatly influence sensory health. Hence proper cleansing and rejuvenating of the sensory organs is needed in protecting us from the rising pandemics. This article is an overview of the Comprehensive analysis of Shalakya tantra references from the Brihat trayee and Sharangadhara Samhita regarding the etiopathogenesis of Janapadhodhwamsa affecting the Uttamangam, its clinical features, its management through kriyakalpam like Nasyam, Dhumapaana, Gandusa, Kavala, Prathisaaranavidhi, Lepa, Murdhinitailam, Karnapurana, Netra prasadana kalpas and its mode of action in strengthening and protecting the sensory perceptions from the damage of non-biological physical agents. Henceforth the review concludes that the Kriyakalpam acts as fundamental habitual preventive practice and serves as the foundation of treatment methods for a cascade of conditions arising as complications to reduce mortality and morbidity.
\end{abstract}

\section{INTRODUCTION}

Ayurveda addresses the human biological factors and connotes its role in nature's biophysical agents like air, water, soil, and season in the balance of every human's health. The universe as a whole is just a part of a syncytium. All humans are just as much as tiny dots interlinked in this echo balance with four domains: the Physical entity (body parts, subparts, Srotas- channels), the functional entity (Vata, Pitta, Kapha), the psychological entity (Sattva, Rajas, Tamas) and the consciousness (Atma). The science of these four works in harmony is beyond mere understandings. The sense organs, like a master, are placed above the supraclavicular region are the physical domain. The perceptions of the sighting, listening, sniffing, perceiving, handling, and commanding promptly of the sense organs are through the functional entity.

\section{Access this article online}

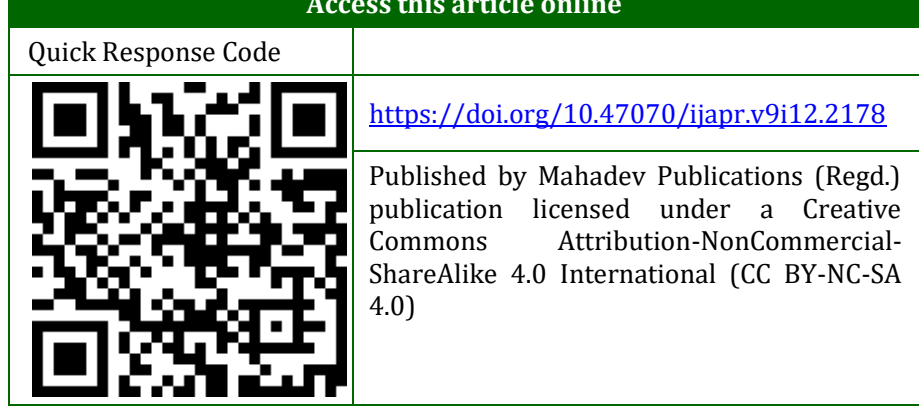

Finally, the interpretation and actions of the perceptions are carried out only by the presence of the psychological and conscious entity. So, any disturbance in one domain will affect the other domains, thus hampers the whole being. Therefore, proper protection of these senses from the excess, non and wrong utilization by habitual Kriyakalpam is the standard basis in curing and preventing the diseases originating from the non-living biophysical events.

\section{Janapadhodhwamsa}

The natural world, whole or in a particular geographical area where humans, animals, and plants indwell are affected by the non-biophysical agents provoked by unrighteous human deeds is called Janapadodhwamsam[1].

In general, there are two causative reasons for diseases of living beings:

1. Those routines to living beings in general;

2. Those specific to every individual. [2]

Janapadhodhwamsam belongs to the former. It hits humankind through nature's biophysical agents: Air, Water, Land, and Season [3], irrespective of the presence of diverse Prakruti (characters and behaviors), Aahara (food and lifestyle), Deha (constitution), Bala (body and mind strength), Satmya (wholesome diet and lifestyle), Sattva (mental stability) and Vayas (age) ${ }^{[4]}$ of the man. These agents in 
normal state help with breathing, survival and cleansing, food and sheltering, and gaining immunity but in the vitiated states it hampers those functions and causes mass destruction to the world. An apparent cause will be there in all happenings of the world, either good or bad. In the last two decades, urbanization and industrialization have also been paid to an outburst of insecurity land, worsening water quality, threatening safe disposal of waste, fulminating the air and noise pollution, and even turned on global warming. All the dots in analyzing the above cause only points out the greed and negligence of humans instigating the non-equilibrium of the non-biological agents. These analyzes are through the concepts of Prajnaparadham, Aasatmya indriyaartha samyoga, and Parinamam. Where the former two are more prone to the change of the latter.

\section{Prajnaparadham}

The Impairments of Intellect, Retention, and Memory ${ }^{[5]}$ is carried out by the affliction of the mind with Rajas and Tama doshas. The unintellectual urbanization; industrialization; deforestation, improper utilization of technology; wrong utilization of artificial intelligence; stocking of black money; illegal procurement of minerals; stealing things, thoughts, speech, and actions of others; invading and killing people; etc. leads to the doomed memory of the benefit of nature in livelihood.

\section{Asatmya indriyartha samyoga}

It divides into three types: Excessive, Non, and Wrong utilization of objects of senses, activities (physical, oral and mental), and season (winter, summer, and rainy season) [6]. The sense faculties with the mind get vitiated and cause an impediment to the respective sense perceptions. If correct utilization happens, they come to normalcy. Therefore, the perception of various objects has to be regulated.

\section{Excessive utilization of objects of senses}

1. Eye-Excessive Gazing at highly illumines substance. E.g.: lightening

2. Ear- Hear uproarious noise or sound coming out of thunder, kettle drum, loud cries, loud speakers, headphones etc.

3. Nose-Acute and intoxicating odors. E.g.: open dump yard, acid aerosol gas, co poisoning, smoking, passive smokers, toxic gases and vapors.

4. Tongue -Various tastes. E.g.: Metallic poisoning in water (Bio magnification)

5. Skin-Contact with Exceedingly cold or hot substances. E.g.: exposure to hot sun (UV radiation)

Non utilization of objects of senses (Ignorance to the surrounding environment)

1. Eye-Not looking at anything. E.g.: eating unhygienic foods.
2. Ear-Not hearing anything at all. E.g.: Not paying heed to elders or other such guidelines given by them.

3. Nose-Not smelling at all. E.g.: residing in a place close to dump yard, not minding the smell and continuing to live there instead of moving out of that place.

4. Tongue-Not using it at all. E.g.: eating very fast, or talking while taking food thereby not using the tongue for mixing as well as tasting, leading to improper digestion.

5. Skin-Not using it at all. E.g.: covering our body with cloth all over, so no exposure to sun; Failure to apply creams to face.

\section{Improper utilization of objects of senses}

1. Eye-seeing things too close or too far away or things that are awful or terrifying or surprising or contemptuous or frightful or deformed and alarming. E.g. prolonged use of gadgets, computers and mobile phones (causing radiation), Seeing the sun and eclipses without protective gear.

2. Ear-Hearing of harsh words, assaulting, insulting and terrifying sounds (noise pollution).

3. Nose-Smell of exceedingly putrid, unpleasant, dirty, purified, cadaverous odor and poisonous gas. E.g.: occupational hazards - harmful chemicals, dye, acid and leather factories.

4. Tongue-Not knowing about the food and its consumption. It includes,

Nature of food -E.g.: stale food; Method by which it is prepared E.g.: cooked in the open or by using dirty water; Combination is healthy or not E.g.: adulteration; Place of preparation of food and eating E.g. unclean kitchen with improper exhaust, unhygienic eating place; Time of intake; age of the person and present health situation-The children and the old are more prone to diseases; The one who consumes food alone; Not following the Rules of eating food.

5. Skin-Use of hot and cold without observing the prescribed order, touching dirty objects etc. E.g.: living in a non hygienic environment (dust). Whoever does not control the senses will soon perish. Ignorance and absence of discipline are the root cause of man's trouble.

\section{Parinama (Kala)}

The transformation of the world happens in two faces, by growth and development or by destruction leading to Seasonal Changes in two waysabnormal seasonal destruction and seasonal destruction. Sunrays are responsible for the changes in the environment in the form of seasons characterized by Sita (cold air), Ushna (hot air), and Varsa (rainwater). These indirectly give distinct features to each day and season. When seasons are ordinary, both 
the land and water will also be usual(having their ordinary qualities). By its use, the activity, span of life, strength, vigor, and vitality of men and animals become augmented. If the season gets abnormality, it will cause the vitiation of land, water, and air and spreads various disasters and diseases. [7]

The current destruction due to the four forms air, water, land, and season ${ }^{[8]}$ are listed below.

1. Cyclone - Air

2. Flood - Water

3. Volcanic Eruption - Land

4. Earthquakes - Land

5. War - Land

6. Communicable Diseases -Season

Even despite unvitiated water and land, the seasons might get vitiated due to the sins committed by men and women, effects of sorcery, the anger of sages and demons, the poisonous substances carried out by the wind, abnormal placement of the planets, wrong movements of the stars, bad qualities of the houses, plastic furniture, pollution emitting vehicles, unpurified precious stones and gems, high-frequency network, uncleansed and chemical emitting household equipment. In short, the Poisonous air disturbs the seasons. One cannot guard himself against the ill effects of polluted seasons. Thus seasons are the most indispensable ones of the four factors, the vitiation of which leads to the complete manifestation of epidemic diseases. So, proper purification of biophysical agents is needed.

\section{Comprehension and Comparison of the Features of Vitiation of Non Biological Agents with the Nidanam of Sense Organs}

Eye

1. Ushnabhi taptashya jala praveshath (Drinking water or taking bath immediately after exposing to sun or heat/ Immediate exposure of climate from sunny to rainy) - Season

2. Dhuma nisevanat (Exposure to poisonous vapors of food) - Air

3. Soka (too much grief) - Land

4. Prashakta samrodana (too much crying in pain)Land

5. Klesa (too much physical strain - excessive breathing, diarrhea, vomiting) - Land

6. Abhighataja (injury by poisonous gas, water microbes and by enemy)- Air and Land ${ }^{[9]}$

Nose

1. Anila rajo (exposure to dusty, smoky air) - Air and Land

2. Pithaena anyaena varinaha (drinking of unknown water)- Water

3. In cloudy day doing nasal inhalations- Season ${ }^{[10]}$

\section{Ear}

1. Jala kreeda (playing in lakes, river, seas which can be polluted ) - Water

2. Karna kandu (exposing to gaseous fumes, water droplets while bathing, microbes in air may cause itchyness in ear) -Air, Water

3. Mitya yogena sabdashya (noise pollution) - Land[11]

\section{Mouth}

1. Matsyamaahishavarahapishithaamakamulakam (Eating meat of animals or birds or which is living in polluted water and land - Land and Water

2. Eating the herbs, vegetables, fruits which is growing in polluted land - Land

3. Not observing proper elimination procedures in respective seasons - Land and Season

4. Divishitho dhantadhaavanam, dhumachardana gundusaanuchitham Improper daily routine practises like brushing, gargling and tongue cleaning with dirty water - Land and Water ${ }^{[12]}$

\section{Head}

1. Dhuma: Exposure to dust - Air

2. Aathapa: More Exposure to sunlight - Air

3. Thushara: Exposure to smog, mist - Air and Land

4. Ambhu kreda: Playing in lakes, rivers and seas which can also be polluted - Water

5. Puro vatah: Exposure to eastern wind - Land and Air

6. Asathmya gandha, dushta aama: Exposure to bad, pungent, putrid smell - Land[13]

\section{Skin}

1. Vipran gurun gharshayatam - disrespecting brahmins and teachers - Land

2. Papam karma cha kurvatam - commiting sins Land[14]

\section{Pathogenesis - Based on Shat Kriyakala}

By the above etiology, Vata dosha gets vitiated[15] to cause the diminution of Bala and Ojas in the body[16]. If the Vyadhikshamatva (host immunity) and Balam are present, further Dosha vitiation doesn't occur. If the patient observes Apathya ahara and Vihara (improper lifestyle) despite low Vyadhikshamtvam (host immunity), there will be an aggravation of vata Kapha or Kapha pitta or Tridoshaja doshas (chayaprakopa) at the source of infection (oral cavity, ear canals, nostrils, conjunctivae, epidermis) or movement of Doshas from the site of entry to the organ of attack, provided the conditions are favorable for the disease genesis. Thereby move out from their respective seats (Prasara) to reach the sense organs and head (Stana samshraya) through specific physiological channels called Srotas either through Nasarandra (nasal pathway) or Tvak (skin pathway) [17] and produces various symptoms and signs based on the Dushyas of Rasa (nutrients), Rakta (blood), Mamsa 
(muscles), Meda (fat), Asthi (bones), Majja (marrow), and Sveda (sweat) of the sense organs (Vyakta) or it can arises much later after the complication of other diseases (Bheda). Thus by this process, the disease manifestations related to the senses are explained.

\section{Clinical Features}

By the above causes, following are the possible features produced in the respective sense organs:

Eye-Krchronmelam (Foreign body sensation), Samrambha (inflammation), Raaga (redness), Tumulaasu rujjaasu (severe pain), Drsti naasha (vision loss), Vartma arshas (Pappilary form of trachoma), Abhishyandam (cattarhal conjunctivitis), Vartma rogas (diseases of eyelid), Brantha netram (abnormal movements of eyes) [18-20]

Nose-Brsham kshava and Kshavatu (sneezing repeatedly), Grhana uparodha (nasal block), Kapha sravam (phlegm like discharge), Svasam (difficulty in respiration), Gandha nigraha (anosmia), Pratishyayam (Rhinitis) ${ }^{[19] .}$

Ear- Karna sulam (pain in ear), Karna sravam (discharge from ear), Krimi karna ${ }^{[19,20]}$

Mouth - Mukha shosham (Dryness of Mouth), Dantha sulam (pain over temples and teeth), Svaraha (loss of voice associated with obstruction in breathing), Mukha paka (mouth ulcers), Kanta rohini (sprouts of muscle growth at root of tongue in the throat, obstruct the passage of throat with fever, fast spreading kills the patient immediately), Kasanam (cough), Lala sravam (excess salivary secretion), Khanta spandanam (dysphagia), Vamathu (vomiting), Jihvaa ashtila (tongue stiffness), Arasa gyanam (loss of taste sensation), Jihva danta oshta mamsanam svayathu (inflammation of tongue, teeth and mouth) [19, 20]
Head -Siro ruk, Shankha shulam (headache), Swayathu (swelling), Darunakam (dandruff), Bahya krimi (lice, nits), Palityam (change in colour of hair), Kalityam (hair loss), Brama, Shirogaurava. ${ }^{[19,20]}$

Skin-Jwara (fever), Masurika (Pox), Kushta (skin diseases), Vipaka (pustules). [19]

\section{Treatment Principles}

Aoupadravikam [21] is a terminology described by sushrutha highlighting the secondary complications pertaining to the sense organs especially eyes, these secondary ailments are the complications of the Aoupasargika[22] diseases like Jvara, Kushtam, Netra Abhishyandam And Yakshma which spreads in human through direct physical contact, exhaled air, eating in same plate, sharing the same shelter and using the same clothes and accessories. Thus the treatment is based on the principle of the head being the root and the body as its branches (when compared to tree), because all Indriyas and prana are having its seat in the head. Henceforth the treatment pertaining to diseases affecting the head will cleanses the entire body too [23].

Uttamangam: Haritha says that the diseases pertaining to the head, eyes, ears, eye brows, temples, throat and neck with their respective Kriya Kalpas like nasal medication, paste, collyrium, oil massage, gargling medicine in mouth etc. is called as Uttamangam[24].

Kriyakalpam: The specific treatment principles carried out for the diseases of the head and neck region are termed as kriyakalpas.

Nasyam - Administration of Tailam, Ghrtam and herbal extract in nasal cavity.[25]

Table 1: the use of the particular Nasyam in the respective uttamanga rogas

\begin{tabular}{|c|c|c|c|c|c|}
\hline Uttamangam & Nasyam & Nasyam & Nasyam & Nasyam & Nasyam \\
\hline & $\begin{array}{l}\text { Brahmana } \\
\text { Nourishing }\end{array}$ & $\begin{array}{l}\text { Virechana } \\
\text { Cleansing }\end{array}$ & $\begin{array}{l}\text { Shamana } \\
\text { Pacifying }\end{array}$ & $\begin{array}{l}\text { Avapidana } \\
\text { Extract of Herbs }\end{array}$ & $\begin{array}{l}\text { Dhmana } \\
\text { Powder of } \\
\text { Herbs }\end{array}$ \\
\hline Eye & $\begin{array}{l}\text { Injury } \\
\text { Refractive } \\
\text { Errors }\end{array}$ & & $\begin{array}{l}\text { Conjunctivitis And } \\
\text { Other } \\
\text { Inflammatory }\end{array}$ & & \\
\hline Ear & $\begin{array}{l}\text { Ear Ache } \\
\text { Tinnitus }\end{array}$ & & Tinnitus & & \\
\hline Nose & $\begin{array}{l}\text { Rhinitis, } \\
\text { Atrophic } \\
\text { Rhinitis }\end{array}$ & $\begin{array}{l}\text { Nasal Polyp } \\
\text { and } \\
\text { Deviated Nasal } \\
\text { Septum } \\
\text { Sinusitis }\end{array}$ & $\begin{array}{l}\text { Rhinitis, } \\
\text { Atrophic Rhinitis }\end{array}$ & $\begin{array}{l}\text { Nasal Polyp } \\
\text { and } \\
\text { Deviated Nasal } \\
\text { Septum, } \\
\text { Swasam }\end{array}$ & $\begin{array}{l}\text { Nasal Polyp } \\
\text { and } \\
\text { Deviated } \\
\text { Nasal } \\
\text { Septum } \\
\end{array}$ \\
\hline Mouth/Throat & $\begin{array}{l}\text { Anorexia } \\
\text { Dryness } \\
\text { Difficulty in } \\
\text { Speech }\end{array}$ & $\begin{array}{l}\text { Anorexia } \\
\text { Thyroid Diseases }\end{array}$ & Stomatitis & & \\
\hline
\end{tabular}


Rengapadmini B et al. Impact of Kriyakalpas Apropos of the Sense Organs and its Management in the Epidemiological Diseases

\begin{tabular}{|l|l|l|l|l|l|}
\hline Skin/Scalp/Head & Hairfall & Dandruff & Premature & & Psychiatric \\
& Facial & Hairfall & Greying, Hairfall & & Diseases \\
& Paralysis & Skin Diseases & Skin Diseases & & \\
& & Facial Paralysis & Fever & & \\
\hline
\end{tabular}

Gudathi nasyam or Pippalyadhi nasyam have been mentioned as treatment in all diseases of eyes, ears, nose, head, neck, lower jaw, throat, shoulders and back. Anutailam, Narayana taila, Masa tailam or Ghrtham can be used as Brhamana or Prayogika nasyam, Tailam based Ushna drugs should be used in
Kapha and Kapha vata avastha, Vasam based Snigdha, Ushna drugs are used in Vata avasta and Ghrtham and Majja bases seeta drugs is used in Pitta avasta.[26]

Dhumapanam: Inhalation of herbal fumigated air through the nose or mouth and exhaled through mouth.[27]

Table 2: The use of the particular Dhumapanam in the respective Uttamanga rogas

\begin{tabular}{|l|l|l|l|}
\hline & Snigdha Nourishing & Madhyama Pacifying & Tikshna Cleansing \\
\hline Eye & $\begin{array}{l}\text { Excessive glandular } \\
\text { secretions }\end{array}$ & $\begin{array}{l}\text { Excessive glandular } \\
\text { secretions }\end{array}$ \\
\hline Ear & Ear ache & Ear ache otitis & $\begin{array}{l}\text { Ear ache } \\
\text { Otitis, } \\
\text { CSOM }\end{array}$ \\
\hline Nose & Atrophic rhinitis & $\begin{array}{l}\text { Rhinitis, } \\
\text { sneezing }\end{array}$ & Rhinitis, sneezing \\
\hline Mouth/throat & $\begin{array}{l}\text { Tooth disorders, } \\
\text { hoarseness of voice, } \\
\text { Kasa }\end{array}$ & $\begin{array}{l}\text { Tooth disorders, anorexia, } \\
\text { Kasa, Swasa }\end{array}$ & $\begin{array}{l}\text { Tooth disorders, anorexia, } \\
\text { excess salivation, Kasa, } \\
\text { Swasa }\end{array}$ \\
\hline $\begin{array}{l}\text { Skin/scalp/ } \\
\text { head }\end{array}$ & $\begin{array}{l}\text { Hair fall, premature } \\
\text { greying, pallor }\end{array}$ & $\begin{array}{l}\text { Premature greying } \\
\text { tissues of the head and neck }\end{array}$ \\
\hline
\end{tabular}

For Samana purpose - Eladigana, Sarjarasa mixed with ghee or oil is used, for Rechana paste of drugs possessing Tiksna properties are used, for Kasaghna root of Kantakari and Marica is used, powders of Nimba and Vacha are used for Vranadhupana purposes.[28]

Kavala-Gandusha-Pratisarana- Mouth gargles and Tongue coating.[29]

Table 3: The use of the particular Kavala-Gandusha-Pratisarana in the respective Uttamanga rogas

\begin{tabular}{|c|c|c|c|c|}
\hline & Shodhana cleansing & Shamana pacifying & Snigdha Nourishing & Ropana Healing \\
\hline Eye & $\begin{array}{l}\text { Vartma arshas } \\
\text { (trachoma) }\end{array}$ & $\begin{array}{l}\text { Inflammation } \\
\text { Redness } \\
\text { and foreign body } \\
\text { sensation in the eye }\end{array}$ & $\begin{array}{l}\text { Vision loss } \\
\text { Pain due to weakness }\end{array}$ & Injury to the Eye \\
\hline Ear & $\begin{array}{l}\text { Ear infection and } \\
\text { discharge }\end{array}$ & Discharge from ear & Ear ache & $\begin{array}{l}\text { Ear Ache and } \\
\text { Discharge }\end{array}$ \\
\hline Nose & Rhinitis, Sneezing & Rhinitis & Rhinitis & \\
\hline $\begin{array}{l}\text { Mouth/ } \\
\text { Throat }\end{array}$ & $\begin{array}{l}\text { Excess salivation } \\
\text { Anorexia } \\
\text { Dental diseases } \\
\end{array}$ & Dental diseases & $\begin{array}{l}\text { Dental diseases } \\
\text { Lip cracks } \\
\text { Dryness of mouth }\end{array}$ & $\begin{array}{l}\text { Dental diseases } \\
\text { Lip cracks }\end{array}$ \\
\hline $\begin{array}{l}\text { Skin/scalp/ } \\
\text { head }\end{array}$ & $\begin{array}{l}\text { Disease of the neck \& } \\
\text { head }\end{array}$ & $\begin{array}{l}\text { Disease of the neck } \\
\& \text { head }\end{array}$ & $\begin{array}{l}\text { Disease of the Neck \& } \\
\text { Head }\end{array}$ & \\
\hline
\end{tabular}

For Snigdha, a paste of Tila (sesame) with water or milk or oil is used. In case of burning sensation of mouth and throat, Tilam, ghee, sugar, milk, honey together can be used. Honey alone used to heal the mouth ulcers and reduce burning. Ghee is used in case of any dental caries. In shaky teeth, Tailam with Saindavam is used. Gargle with Kanjika is good for dryness of mouth and bad taste. Triphala and honey mitigates Kapha, Rakta and Pitta. ${ }^{[30]}$

Karnapurana -Filling of oil or medicated liquids in ear ${ }^{[31]}$

Ear and Head: Ear Ache And Headache, Itching In Ear, Tinnitus, Deafness

For ear ache and itching in the ear Kshara tailam is used. For headache, tinnitus and deafness Vilvagomutra tailam is used.[32] 
Int. J. Ayur. Pharma Research, 2021;9(12):105-114

Karnaprakshalanam and Karna Dhupanam -Ear washing and Ear fumigation.

Ear and Head: Itching In Ear, Ear Infection, Pus Discharge

For itching and ear infection, Triphala kashayam or Shigrumula swarasam is used for washing the ear canal. [33]

Mukhalepa- Topical application.

Table 4: Below shows the use of the particular Mukhalepa in the respective Uttamanga rogas

\begin{tabular}{|l|l|l|l|}
\hline & Doshaha Pacifying & Vishaha Cleansing & Varnya Nourishing \\
\hline Eye & $\begin{array}{l}\text { Eye Pain Excessive } \\
\text { Lacrimation }\end{array}$ & $\begin{array}{l}\text { Eye Pain with } \\
\text { Redness }\end{array}$ & \\
\hline Skin & Pimples & Skin Diseases & $\begin{array}{l}\text { Normal Tone and } \\
\text { Complexion }\end{array}$ \\
\hline
\end{tabular}

For Vishahara, paste of Durva and Nisha is used. For Doshahara, paste of Madhuka and chanDana can be used. For Varnya, paste of Raktachandana, Manjistha, and Lodhra are used. [34]

Murdha Tailam - Oleation of head.

Table 5: Below shows the use of the particular Murdha tailam in the respective Uttamanga rogas

\begin{tabular}{|l|l|l|l|l|}
\hline & $\begin{array}{l}\text { Abhyangam } \\
\text { Oil Application on } \\
\text { Head }\end{array}$ & $\begin{array}{l}\text { Pariseka } \\
\text { Pouring of Medicated } \\
\text { Liquids on Head }\end{array}$ & $\begin{array}{l}\text { Shiropichu } \\
\text { Application of Paste } \\
\text { Over Head }\end{array}$ & $\begin{array}{l}\text { Shirovasti } \\
\text { Retention of Oil } \\
\text { Over Head }\end{array}$ \\
\hline Eye & $\begin{array}{l}\text { Diseases Due To Over } \\
\text { Straining }\end{array}$ & Burning Sensation & $\begin{array}{l}\text { Paralysis of Eye } \\
\text { Muscles }\end{array}$ & $\begin{array}{l}\text { Refractive Errors } \\
\text { of the Eye }\end{array}$ \\
\hline Ear & Age Related Problems & & & $\begin{array}{l}\text { Dryness of Nasal } \\
\text { Mucosa }\end{array}$ \\
\hline Nose & & & $\begin{array}{l}\text { Dryness of the } \\
\text { Oral Cavity }\end{array}$ \\
\hline $\begin{array}{l}\text { Skin/Scalp/ } \\
\text { Head }\end{array}$ & $\begin{array}{l}\text { Itchy Dry Scalp, Dry } \\
\text { Skin } \\
\text { Headache }\end{array}$ & $\begin{array}{l}\text { Infections of Scalp } \\
\text { Headache, Burning and } \\
\text { Suppurate Ulcers in } \\
\text { Scalp Headache }\end{array}$ & $\begin{array}{l}\text { Hair Fall } \\
\text { Splitting of Hair } \\
\text { Burning Sensation } \\
\text { in Scalp, Headache }\end{array}$ & $\begin{array}{l}\text { Loss of Sensation } \\
\text { in Scalp } \\
\text { Facial Palsy } \\
\text { Headache }\end{array}$ \\
\hline
\end{tabular}

For burning sensation and fatigue Narikela jala, cool water or milk are used. For diseases of Vata and Pitta ghrita or Tailam is used. Takram is used for Kaphavata diseases. ${ }^{[35]}$

Ashchotana- Application of medicated liquid in the form of drops in the eyes.

Eye: Pricking Pain, Itching, Feeling of friction in the Eyes, Excessive Lacrimation, Burning Sensation, Eye Redness.

It is warm in case of pain, Lukewarm in case of itching and cold in case of burning sensation. [36]

Anjanam-Applications of collyrium in eyes

Table 6: Below shows the use of the particular Anjanam in the respective Uttamanga rogas

\begin{tabular}{|l|l|l|l|}
\hline & $\begin{array}{l}\text { Lekhana- } \\
\text { scrapping }\end{array}$ & $\begin{array}{l}\text { Ropana- } \\
\text { healing }\end{array}$ & $\begin{array}{l}\text { Prasadana- } \\
\text { nourishing }\end{array}$ \\
\hline Eye & $\begin{array}{l}\text { Corneal } \\
\text { opacities }\end{array}$ & Ulcerations & $\begin{array}{l}\text { Inflammatory } \\
\text { conditions }\end{array}$ \\
\hline
\end{tabular}

For Lekhana Anjanan herbs having astringent, sour, salt, and pungent tastes and hot potency is selected, for Ropana Anjana it is prepared from herbs of bitter taste and for Prasadana Anjana from herbs of sweet taste and cold potency. [37]
Sekam- washing of the eye with medicated decoctions

Table 7: Below shows the use of the particular Sekam in the respective Uttamanga rogas

\begin{tabular}{|l|l|l|l|}
\hline & $\begin{array}{l}\text { Snehana- } \\
\text { Nourishing }\end{array}$ & Ropana-Healing & $\begin{array}{l}\text { Lekhana- } \\
\text { Scrapping }\end{array}$ \\
\hline Eye & $\begin{array}{l}\text { Pain in the } \\
\text { Eye, } \\
\text { Refractive } \\
\text { Errors }\end{array}$ & $\begin{array}{l}\text { Inflammation } \\
\text { And Redness }\end{array}$ & Trachoma \\
\hline
\end{tabular}

For Ropana seka, Triphala kashayam is used. Use of luke warm milk mixed with Saindhava is used for Snehana seka. Lodhra powder fried in ghee and mixed with warm water is used for pain. [38]

Tarpanam and Putapaka - application of ghee and medicated juices in the eyes for a stipulated time.

Table 8: Below shows the use of the particular Tarpanam- Putapaka in the respective Uttamanga rogas

\begin{tabular}{|l|l|}
\hline Eye & $\begin{array}{l}\text { Fatigued, dry or injured eye, loss of eye } \\
\text { lashes, clouded vision, black spots in the field } \\
\text { of vision, redness, conjunctivitis, weakness } \\
\text { of ocular muscles and refractive errors }\end{array}$ \\
\hline Head & Headache \\
\hline
\end{tabular}


Snehana putapaka, sneha has base with drugs of Jivaneeya gana, macerated with milk, for Vata imbalance disorder. Lekhana Putapaka (scraping type) by making use of Mastu (whey), water of yoghurt macerated with the paste of liver of animal and birds, pearls, ash of iron and copper, Saindhava- salt, Srotonjana (Antimony sulphide), Shankha (ash of conch shell), Phena- (sea foam), cuttlefish and Ala (orpiment) - for Vata - Kapha imbalance disorder. Prasadana Putapaka (soothing) by the use of cow milk / breast milk macerated with the liver, marrow, Muscle fat, Muscle of intestines and heart of animals and birds and drugs of sweet taste, and mixed with ghee- in weakness of the eyes, vision, in disorders of Vata Pitta and Rakta and for the healthy person. [39]

\section{Bidalakam and Pindi}

The application of medical paste over the eyelid for a stipulated time is known as Bidalakam. Bandaging a bolus of medicines over a closed eye is Pindi.

Eye: Conjunctivitis, itching \& odema around the eyes, burning and redness.

For Netra kandu and Shotha, Pindi of Nimba stalk, and Saindhava lavana is used. For burning sensation and redness Pindi of Amalaki is used. For all diseases of the eyes Bidalaka of Rasanjanam is used. [40]

\section{Probable mode of action of the Kriyakalpanas} pertaining to the Uttamangam:

\section{Nasyam, Dhumapanam: Urdhva Jathru Ghata Roga}

Almost all the diseases that are infectious are air-borne and the nasal mucosa is the first part which is exposed to the pathogens. As the nasal tissue is highly vascularized it makes an attractive site for rapid and efficient systemic absorption of medicine bypassing the liver and GIT. Thus medicines administered through this route will have better bio availability. Prophylactically, it strengthens the nasal mucosa and therapeutically, the nasal administration of medicines destroys the pathogens on direct contact and protects the other senses as there is a complex circulatory link between them. [41]

\section{GandūSha, Dhumapanam, Kavalam, Pratsiaranam: Oral and Throat Diseases}

Some of the epidemiological diseases are transmitted through the oral route. Gandusha increases the salivary secretions through a complex pathway which acts as a barrier against transmission of infection through the oral route. [42]

\section{Tarpana, Putapakam, Anjanam, Aschothanam, Sekam: Eye Diseases}

These methods are mainly used for treating the symptoms related to the eyes alone. The cornea and the conjunctiva are the main sites of drug absorption. Water soluble drugs easily absorbed through the vessel wall i.e. permeability and vascularity. Colloids are more slowly absorbed than crystalloids. Fat soluble substances reach the circulation more slowly than water soluble drug as in Tarpana and Putapaka. Ointment increases bioavailability of drug by increasing the tissue contact time and by preventing dilution and drainage of active ingredients in different collyrium. These methods are to be selectively applied based on the nature of the infection and symptoms. e.g. Tarpana in Vata predominant diseases are done for a longer duration as compared to Pittaj and Kaphaj predominant diseases. Decoctions contains varying amount of saponins increases the permeability of epithelium by reducing the surface tension. [43]

\section{Karnapurana, Karnaprakshalana, Karnadhoopana: ear diseases and headache}

The ear canal is lined by thin keratinized stratified squamous epithelium covering fibrous stroma, enriched with collagenous villi which helps in maximum chances of absorption. The medicine which are in aqueous and lipid phase will get absorbed easily depending upon the contact time. Karna dhoopana dilates the blood vessels and helps in oxidation of blood thereby leading to adequate tissue perfusion and oxygenation. Thus, it reduces inflammation, itching and eliminates infection. [44]

\section{Mukhalepam: Skin and Eye Diseases}

Mukhalepa is applied against the direction of hair follicles. This facilitates the quicker absorption of active components of the drug through hair follicles, sweat glands and blood capillaries. ${ }^{[45]}$

\section{Murdhatailam: Head Diseases}

Shirovasti works on the principle of Law of Energy conservation. It modulates the secretions of various neurotransmitters and hormones by adjusting the intensities of electromagnetic waves of brain. Therefore, the intellect, retention and memory is restored [46]

\section{DISCUSSION}

The significance of the shalakya tantra references in this article is evident by comparing the common pandemics of the last two decades like SARS, H1N1, EBOLA, MERS, NIPAH VIRUS, and COVID19 with its clinical features and complications of sense organs. SARS causes Conjunctivitis, Conjunctival Hyperemia, Ocular Irritation, Foreign Body Sensation, Epiphora, and Chemosis as symptoms and signs of the eye; Deafness in case of involvement of ear; Rhinitis and Nose Block as symptoms of the nose, Throat pain, Hoarseness, and Dry Cough and headache. H1N1 causes Acute Conjunctivitis, Retinopathy, Uveal Effusion Syndrome and Optic Neuritis, Middle Ear Infection and Sudden Hearing Loss, Nasal Secretions, Throat Ache, Purpuric Rash, Headache, Numbness, Paresthesia, Drowsiness, and Coma when the respective senses are involved. EBOLA causes Uveitis, 
Severe Vision Impairment, Blindness, Cataract, Retinal Scarring, Optic Neuropathy, Hypotony and Phthisis Bulbi, Sore Throat, Bleeding from The Nasal Orifices, Nonspecific Maculopapular Rash, which initially presents on the upper arms, flexor forearms, and upper legs, in a centripetal fashion, Seizures, Memory Loss, Headaches, Cranial Nerve Abnormalities and Tremor which arise when the higher faculty is involved. MERS causes Nasal Secretions, Sore Throat, Possible Rash, headache, altered level of consciousness ranging from confusion to coma, ataxia, And focal motor deficit. NIPAH VIRUS causes the usual respiratory complaints as seen in the flu and Acute Encephalitis with altered sensorium in the later stages. COVID 19, the most recent and widespread of them all causes Acute Conjunctivitis Symptoms, Including Eye Redness, Ocular Irritation, Eye Soreness, Foreign Body Sensation, Tearing, Mucoid Discharge, Eyelid Swelling, Congestion and Chemosis, Otitis Media, Itchy Running Nose, Anosmia, Sinusitis, Rhinitis, Nose Block, Sore Throat, Rashes, Headache, and Brain Fog as symptoms affecting the senses and the brain. Although the rate of deaths from communicable diseases of the last 20 years is in decline. Still, it is a major challenge in lowand middle-income countries. The natural resources in these countries face a host of serious threats, all of which are caused primarily by human activity like sedimentation, pollution, climate change, deforestation, landscape changes, and urban growth resulting in the spread or transmission of pollutants/ agents to the host. Other mechanisms like inhalation, ingestion, hearing, a bite of a vector, direct skin contact, contact with bodily fluids, contact with contaminated articles, and so on also make the immune level in our body very low. For which reconstruction of immunity is needed. These pandemics are mostly viral in origin, leading to the vitiation of Vata and Kapha doshas and produce most of the symptoms and complications in the sensory organs. A vaccine is not likely to be available at first. So, it will be easier to practice Brahmaneeya and Prayogika kriyakalpas-rasanjanam, Navana nasyam, Kavalam, Gandusham, Dhupanam, Siro abhyanga in order as a daily and seasonal cleanser to produces local and systemic immunity more quickly and forms as a method for preventing the spread of disease. The treatment of the diseases of sense organs initially starts with the Kriyakalpas having the properties of Vata kaphahara Lekhaneeya, Ropaneeya, Samananeeya, and Sodhaneeya procedures followed by the administration of Brahmaneeya and Prayogika kriyakalpas to cleanse and rejuvenate the natural seat of Kapha in the Shira pradesham and also controls the external vata vitiation. It is said that the saliva- The Biological Fluid Marker which helps in figuring out the low immunity in our body by producing a symptom of dry mouth and is the root cause of many diseases, is also an aid to diagnose disease caused due by pollution. Administration of Nasyam, Gandusham, Kavalam, and Pratisaraniyam restores the salivary contents and increases immunity. The COVID 19 spreading pandemically worldwide can be treated and protected by safeguarding the salivary secretions through habitual practices of Gandusham, Nasyam, etc. which helps in the secretion of saliva, maintains normal $\mathrm{pH}$, heals salivary mucosa, and detoxifies it.

\section{CONCLUSION}

Pandemic diseases are unmentioned in the ancient texts at the same time the approaches of understanding are dealt with in detail in Samhitas. This principle helps in listing out the etiology, pathogenesis, clinical features, and treatment protocols. At this point, it's not good enough to say that Adharma prevalent in society, be it at the individual level or the level of the community is held accountable for all the destruction either in the present or previous life. The fruits of that Karma have to be experienced by him without any doubt. Therefore, Improper sensory perceptions are the prime reason for disease outbreaks and death of the individual. Acharya's have created a separate branch of medicine called Shalakya tantram to focus on protecting, safeguarding, and curing the diseases related to sense organs. Hampering of the sense organs pays loss to life. So, Learning the habitual Kriyakalpam helps to reduce the spread of serious diseases internally and externally and increases disease resistance.

\section{REFERENCES}

1. Prof. Madan Mohan Jha, Srujan jha online application, Shabdakalpadruma, vidahi shabdartha.

2. Acharya Yadavji Trikamji, editor, commentary 'Ayurveda Deepika' of Chakrapanidatta on Charakasamhita by Agnivesha, Vimana sthana; Janapadodhwamsaniyam: chapter-3, verse 2 . Varanasi: Chowkhamba Surbharathi Prakashan, $2011 ; 240$

3. Dr.R.K.Sharma \& Bhagwan Dash, Charaka Samhitha of Acharya Charaka, Vimanasthana; Janapado dhwamsaniyam: Chapter-3, verse 6, Varanasi Chowkhamba Sanskrit series, 2018; 142

4. Dr.R.K.Sharma \& Bhagwan Dash, Charaka Samhitha of Acharya Charaka, Vimanasthana; Janapado dhwamsaniyam: Chapter-3, verse 5, Varanasi Chowkhamba Sanskrit series, 2018; 142

5. Dr.R.K.Sharma \& Bhagwan Dash, Charaka Samhitha of Acharya Charaka, Saarirasthana; Katithadhathu purishiyam: Chapter-1, verse 99-108, Varanasi: Chowkhamba Sanskrit series, 2018; 149

6. Dr.R.K.Sharma \& Bhagwan Dash, Charaka Samhitha of Acharya Charaka, volume 2, Sutrasthana; Tisraisana: Chapter-9, verse 37-41, Varanasi: Chowkhamba Sanskrit series, 2018; 221-5 
7. Dr.R.K.Sharma \& Bhagwan Dash, Charaka Samhitha of Acharya Charaka, volume 2, Sutrasthana; Tisraisana: Chapter-9, verse 42, Varanasi: Chowkhamba Sanskrit series, 2018; 225-6

8. Dr.R.K.Sharma \& Bhagwan Dash, Charaka Samhitha of Acharya Charaka, Vimanasthana; Janapado dhwamsaniyam: Chapter-3, verse 6-8, Varanasi: Chowkhamba Sanskrit series, 2018; 142-4

9. Dr.Hemanta panigrahi, 1 st edition, Susrutha samhitha uttar tantra with special notes on Dalhana commentary, volume 1, uttarasthana; Aoupadravikam adhyaaya: chapter-1, verse 26-27, Delhi: Chaukhambha orientalia, 2005; 19-20

10. Prof.K. R. Srikantha Murthy, 11th edition, Ashtanga Hrudayam of Vagbhatha, Uttarasthana; Nasa Roga vijnaaniya: Chapter 19, Verse 1-3a. Varanasi Chowkhamba Sanskrit series, 2020; 173.

11. Prof.K. R. Srikantha Murthy, 11th edition, Ashtanga Hrudayam of Vagbhatha, Uttarasthana; Karna roga vijnaaniya adhyaya: Chapter 17, Verse 1-3. Varanasi Chowkhamba Sanskrit series, 2020; 155.

12. Prof.K. R. Srikantha Murthy, 11th edition, Ashtanga Hrudayam of Vagbhatha, Uttarasthana; Mukharoga vijnaaniya adhyaya: Chapter 21, Verse 1-3. Varanasi Chowkhamba Sanskrit series, 2020; 184.

13. Prof.K. R. Srikantha Murthy, 11th edition, Ashtanga Hrudayam of Vagbhatha, Uttarasthana; Siro roga vijnayam: Chapter 23, Verse 1-3. Varanasi Chowkhamba Sanskrit series, 2020; 219.

14. Dr.R.K.Sharma \& Bhagwan Dash, Volume 3, Charaka Samhitha of Acharya Charaka, chikitsasthana; Kushtachikitsitham: Chapter-7, verse 8, Varanasi: Chowkhamba Sanskrit series, 2018; 319

15. Dr.R.K.Sharma \& Bhagwan Dash, Volume 3, Charaka Samhitha of Acharya Charaka, chikitsasthana; Jwarachikitsitham: Chapter-3, verse 38, Varanasi: Chowkhamba Sanskrit series, 2018; 121

16. Prof.K.R.Srikantha Murthy, Susruta Samhita, volume 1, Sutrasthanam; Dosadhathumala kshayavrddhi vijnaniya: chapter -15, verse 23-24, Varanasi: Chaukambha orientalia, 2010; 105

17. Prof.K.R.Srikantha Murthy, Susruta Samhita, volume 1, Sutrasthanam; Rutucaryaa adhyaaya: chapter -6 , verse 19, Varanasi: Chaukambha orientalia, 2010; 42

18. Dr.Hemanta panigrahi, 1 st edition, Susrutha samhitha uttartantra with special notes on Dalhana commentary, volume 1, Uttarasthana; Nayanaabhighaata Pratisedha adhyaaya: chapter19, verse 3, Delhi: Chaukhambha orientalia, 2005; 443-444.

19. Prof.K.R.Srikantha Murthy, Susruta Samhita, volume 1, Sutrasthanam; Rutucaryaa adhyaaya: chapter -6 , verse 19, Varanasi: Chaukambha orientalia, 2010; 42

20. Priya vrat sharma, Susruta Samhitha, volume 3, Kalpasthanam; Annapanaraksha kalpam: chapter 1, verse 35-71, Varanasi: Chaukambha visvabharati, 2014, 7-12.

21. Dr.Hemanta panigrahi, 1 st edition, Susrutha samhitha uttar tantra with special notes on Dalhana commentary, volume 1, uttarasthana; Aoupadravikam adhyaaya: chapter-1, verse 1, Delhi: Chaukhambha orientalia, 2005; 3

22. Prof.K.R.Srikantha Murthy, Susruta Samhita, volume 1, Nidanasthanam; Kushta nidanam: chapter -5, verse 33-34, Varanasi: Chaukambha orientalia, 2010; 502

23. Prof.K. R. Srikantha Murthy, 11th edition, Ashtanga Hrudayam of Vagbhatha, Uttarasthana; Urdhvanga cikitsa: Chapter 24, Verse 58. Varanasi: Chowkhamba Sanskrit series, 2020; 234.

24. Dr.R.K.Sharma \& Bhagwan Dash, Charaka Samhitha of Acharya Charaka, volume 1 Sutrasthamna ; Kiyenthaesirasiyam adhyaya, Chapter-17, verse 12, Varanasi : Chowkhamba Sanskrit series, 2018; 312.

25. Pandey, A. K., \& Mishra, R. K. Nasya and Ayurveda: A classical review based on ancient Ayurvedic treatise. International Journal of Unani and Integrative Medicine 2019; 3(4): 103-109.

26. Prof.K.R.Srikantha Murthy, Sarangadhara Samhitha, Uttamakhanda; Nasya vidhi, chapter 8, verse 1-62, Varanasi: Chowkambha Orientalia, 2009; 222-229.

27. Prof.K.R.Srikantha Murthy, Sarangadhara Samhitha, Uttamakhanda; Dhumapana vidhi, chapter 9, verse1-6, Varanasi: Chowkambha Orientalia, 2009; 230.

28. Prof.K.R.Srikantha Murthy, Sarangadhara Samhitha, Uttamakhanda; Dhumapana vidhi, chapter 9, verse19-20, Varanasi: Chowkambha Orientalia, 2009; 232.

29. Prof.K.R.Srikantha Murthy, Sarangadhara Samhitha, Uttamakhanda; Gandushakavala pratisarana vidhi, Chapter 10, verse1-7, Varanasi: Chowkambha Orientalia, 2009; 233.

30. Prof.K.R.Srikantha Murthy, Sarangadhara Samhitha, Uttamakhanda; Gandushakavala pratisarana vidhi, chapter 10 , verse8-13, Varanasi: Chowkambha Orientalia, 2009; 233-34.

31. Prof.K.R.Srikantha Murthy, Sarangadhara Samhitha, Uttamakhanda; Lepa, murdhataila, karnapurana vidhi, chapter 11, verse129-132, Varanasi: Chowkambha Orientalia, 2009; 249-250.

32. Dr.Hemanta panigrahi, 1 st edition, Susrutha samhitha uttar tantra with special notes on Dalhana commentary, volume 1, uttarasthana; 
Karnaroga pratisedha adhyaaya: chapter-21, verse 35, Delhi: Chaukhambha orientalia, 2005; 506

33. Prof.K.R.Srikantha Murthy, Sarangadhara Samhitha, Uttamakhanda; Lepa, murdhataila, karnapurana vidhi, chapter 11, verse151-, Varanasi: Chowkambha Orientalia, 2009; 222-252

34. Prof.K.R.Srikantha Murthy, Sarangadhara Samhitha, Uttamakhanda; Lepamurdhataila karnapurana vidhi, chapter 11, verse1-9, Varanasi: Chowkambha Orientalia, 2009; 235-236

35. Dr T Sree kumar, 4th edition Ashtangam hridyam, English translation and commentary, volume 2, Sutrasthanam; Gandushadi vidhi: chapter-22 verse 23-26.Thrissur: Harishree hospital, 2013; 130.

36. Dr T Sree kumar, 4 th edition Ashtangam hridyam, English translation and commentary, volume 2, sutrasthanam; Ashchotanaanjana vidhi chapter -23 verse 1.Thrissur: Harishree hospital, 2013; 136.

37. .Dr T Sree kumar, 4 th edition Ashtangam hridyam, English translation and commentary, volume 2, sutrasthanam; Aschotanaanjana vidhi : chapter -23 verse 8-11. Thrissur: Harishree hospital, 2013; 137-138.

38. Prof.K.R.Srikantha Murthy, Sarangadhara Samhitha, Uttamakhanda; Netraprasadana karma, chapter 13, verse 2-12, Varanasi: Chowkambha Orientalia, 2009; 258-259.

39. Dr T Sree kumar, 4 th edition Ashtangam hridyam, English translation and commentary, volume 2,

\section{Cite this article as:}

Rengapadmini B, Balasubramaniam S, Anita Patel. A Limelight on the Affirmative Impact of Kriyakalpas Apropos of the Sense Organs and its Management in the Epidemiological Diseases-An Overview. International Journal of Ayurveda and Pharma Research. 2021;9(12):105-114. https://doi.org/10.47070/ijapr.v9i12.2178

Source of support: Nil, Conflict of interest: None Declared sutrasthanam; Tarpanaputapaka vidhi: chapter -24 verse 13-16.Thrissur: Harishree hospital, 2013; 146-147.

40. Prof.K.R.Srikantha Murthy, Sarangadhara Samhitha, Uttamakhanda; Netraprasadana karma, chapter 13, verse31-36, Varanasi: Chowkambha Orientalia, 2009; 262

41. VipinKumar. A Conceptual Study on Mode of Action of Nasya. International Journal of Ayurveda and Pharma Research. 2017;5(7):100-102.

42. Guruprasad, K. Role of Ayurveda in Management of Oral Health-A Conceptual Study. Int J Health Sci Res. 2019; 9(4):269-274.

43. Bhardwaj, A. (2019). Netra Kriya Kalpa-A Critical Review. Journal of Ayurveda and Integrated Medical Sciences, 4(02), 121-125.

44. Bedarkar, P., Patgiri, B. J., \& Chaudhari, S. Y. Dhoopana Karma: A Review Through Brihatrayi. IAMJ: February- March, 2017; 316-325.

45. Chaudhari, T. G., Sneha, K., Mukund, D., \& Pallavi, J. (2017). Role of Lepakalpana for improving Beauty of Skin wsr to Mukhalepa. International Journal of Ayurveda and Pharma Research.

46. Divya, K., Tripathi, J. S., \& Tiwari, S. K. (2013). An appraisal of the mechanism of action of shirodhara. Annals of Ayurvedic Medicine, 2, 11417.

*Address for correspondence
Dr. Rengapadmini B
PG Scholar,
Dept. of Shalya Tantra,
Sri Jayendra Saraswathi Ayurveda
College And Hospital, Chennai,
Department of Ayurveda, Sri
Chandrasekharendra Saraswathi
Vishwa Mahavidyalaya, Kanchipuram
(Deemed University).
Email: pathumini05@gmail.com

Disclaimer: IJAPR is solely owned by Mahadev Publications - dedicated to publish quality research, while every effort has been taken to verify the accuracy of the content published in our Journal. IJAPR cannot accept any responsibility or liability for the articles content which are published. The views expressed in articles by our contributing authors are not necessarily those of IJAPR editor or editorial board members. 